\title{
Autoimmune haemolysis: an 18-year study of 865 cases referred to a regional transfusion centre
}

\author{
R J SOKOL， S HEWITT, BARBARA K STAMPS
}

\begin{abstract}
Clinical and serological records of 865 patients with confirmed autoimmune haemolysis (AIH)-a much larger series than any previously reported-were critically reviewed and analysed. A proposed new classification for AIH based on serological findings differs from traditional classifications in that a new category of "mixed" AIH has been defined in which both "warm" and "cold" autoantibodies are present, and both are capable of causing haemolysis. Patients in this mixed group tend to have severe disease that may run a chronic intermittent course. The presentation of cold agglutinin disease is much more variable than has been seen in previous studies, haemolysis due to low titre autoantibodies being common. The AIH associated with pregnancy, usually considered as being of bad prognosis, is often mild and self limiting in the absence of other associated disorders.
\end{abstract}

\section{Introduction}

Autoimmune haemolysis ( $\mathrm{AIH})$ is a well-recognised clinical problem requiring skilled management and investigation. It is rare, however, for any one hospital to see more than five or six new cases a year. The Trent Regional Blood Transfusion Centre, which serves a population of roughly 4.7 million people in an area of 6500 square miles (16 $828 \mathrm{sq} \mathrm{km}$ ), acts as an immuno-

Regional Blood Transfusion Centre, Sheffield S5 7JN R J SOKOL, MD, MRCPATH, consultant haematologist, deputy director S HEWITT, FIMLS, chief medical laboratory scientific officer BARBARA K STAMPS, FIMLS, senior medical laboratory scientific officer haematology reference centre for hospitals within the Trent Region and South Humberside. Blood samples from patients with $\mathrm{AIH}$, or in whom this diagnosis is suspected, are referred to this centre and have provided a unique opportunity to study a great many cases.

\section{Materials and methods}

Examination of the results of investigations on blood samples referred to the immunohaematology reference laboratory from September 1961 to 31 December 1980 showed that 865 patients were confirmed to have AIH. The clinical records and serological worksheets were analysed in detail. Patients found to have paroxysmal nocturnal haemoglobinuria, glucose 6-phosphate dehydrogenase (G6PD) deficiency, haemolytic anaemia associated with polyagglutinable cells, or in whom there was insufficient evidence to warrant a diagnosis of AIH were not considered further.

Full clinical details, with particular attention to drug history and disorders known to be associated with autoimmune haemolytic anaemia (AIHA), were recorded when possible. The relevant haematological, serological, and biochemical findings of the referring hospital and the time of year of presentation were noted. Male patients with ages ranging from 5 months to 97 years and female patients ages ranging from 2 years to 89 years were grouped by age into decades. Details of the total male and female population at risk during the period of study were obtained from the medical statistics department at the Trent Regional Health Authority.

Whenever possible, examination was performed on serum from blood that had been kept at $37^{\circ} \mathrm{C}$ during clotting and separation, and on red cells taken from whole blood anticoagulated with EDTA. The following investigations were routinely carried out:

(1) $\mathrm{ABO}$ and rhesus $(\mathrm{Rh})$ genotyping.

(2) Direct antiglobulin tests using broad-spectrum and anticomplement reagents.

(3) Antibody investigations.

(a) Antibodies were detected in serum using saline, albumin, papain, and by antihuman globulin methods at $37^{\circ} \mathrm{C}$ and in saline at $18^{\circ} \mathrm{C}$. 
(b) The presence of haemolysins was determined by testing patients' complement-enriched serum against pooled $\mathrm{O}$ cells at $18^{\circ} \mathrm{C}$ and $37^{\circ} \mathrm{C}$ at $\mathrm{pH} 6.8$, and against papainised $\mathrm{O}$ cells at $37^{\circ} \mathrm{C}$ at normal $\mathrm{pH}$.

(c) Donath-Landsteiner type antibodies (biphasic haemolysins) were detected using an indirect method.

(d) The antibody activity in red cell eluates was investigated using indirect antiglobulin techniques and by testing against prepapainised red cells.

(e) Antibodies in serum and eluates were tested for avidity and specificity using routine red cell panels.

(4) Drug-dependent haemolysis was investigated where appropriate.

(5) Haptoglobin estimation

(6) Serum electrophoresis.

Depending on preliminary findings, further investigations were carried out as indicated:

(7) On occasions, when definite antibody specificity was suspected, further absorption and elution studies using selected red cells were carried out on both serum and eluates.

(8) Serum immunoelectrophoresis.

(9) Ham's test and sucrose lysis test.

(10) Serological tests for syphilis.

(11) Screening test for G6PD deficiency.

Other tests, including direct antiglobulin tests using specific reagents (anti-IgA, IgG, IgM, C3d, C3b, C4), antibody concentration using dialysis, and antibody separation using gel chromatography with Sephadex G-200, have been introduced since the survey began and will be reported where relevant.

Patients confirmed to have AIH were classified by disease association and divided into groups depending on whether the antibody was mainly active at $37^{\circ} \mathrm{C}$ ("warm" $\mathrm{AIH}$ ), at $18^{\circ} \mathrm{C}$ ("cold" $\mathrm{AIH}$ ), or into a group in whom both warm and cold antibodies were found and the serological reactions were such that both antibodies were considered capable of causing the haemolysis ("mixed" AIH).

\section{Results}

Table I shows the distribution of the 865 patients by disease

TABLE I-Distribution of 865 patients with AIH based on disease association and serological findings

\begin{tabular}{|c|c|c|c|c|}
\hline \multirow{2}{*}{ Condition } & \multirow[t]{2}{*}{ Warm AIH } & \multicolumn{2}{|c|}{ Cold AIH } & \multirow[t]{2}{*}{ Mixed AIH } \\
\hline & & \multicolumn{2}{|r|}{$\mathrm{PCH}$} & \\
\hline $\begin{array}{l}\text { Idiopathic AIH } \\
\text { Drug-related AIH }\end{array}$ & $\begin{array}{l}191 \\
156\end{array}$ & 131 & 5 & 27 \\
\hline \multicolumn{5}{|l|}{ Neoplasia } \\
\hline Lymphoid neoplasms & & & & \\
\hline $\begin{array}{l}\text { Non-Hodgkin's lymphoma } \\
\text { Angjojmmunoblastic }\end{array}$ & 20 & 16 & 0 & 5 \\
\hline $\begin{array}{l}\text { Angiommunoolestic } \\
\text { lymphadenopathy }\end{array}$ & 0 & 0 & 0 & 1 \\
\hline Chronic lymphocytic leukaemia & 45 & 2 & 0 & $\frac{1}{2}$ \\
\hline Myeloma & 4 & 3 & 0 & 0 \\
\hline Macroglobulinaemia & 1 & 3 & 0 & 0 \\
\hline Thymoma & 1 & 0 & 0 & 0 \\
\hline Hodgkin's disease & 9 & 7 & 0 & 3 \\
\hline Ovarian tumours & 2 & 1 & 0 & 2 \\
\hline Carcinoma (non-ovarian) & 24 & 23 & 0 & 3 \\
\hline Non-lymphoid leukaemias & 2 & 4 & 0 & 1 \\
\hline \multirow{2}{*}{\multicolumn{5}{|c|}{ Infection }} \\
\hline & & & & \\
\hline Pneumonia-mycoplasma & 0 & 8 & 0 & 0 \\
\hline Pneumonia-"viral" and unspecified & 2 & 18 & 0 & 0 \\
\hline Respiratory infections-unspecified & 1 & 12 & 6 & 1 \\
\hline "Flu-like" illness & 2 & 3 & 3 & 0 \\
\hline Infectious mononucleosis & 0 & 10 & 0 & 0 \\
\hline Infectious hepatitis & 2 & 1 & 0 & 0 \\
\hline Chicken pox & 0 & 0 & 1 & 0 \\
\hline Meningitis & 0 & 0 & 1 & 0 \\
\hline Tuberculosis & 0 & 2 & 0 & 0 \\
\hline Infection-unspecified & 1 & 2 & 1 & 1 \\
\hline \multicolumn{5}{|l|}{ Collagen diseases } \\
\hline Systemic lupus erythematosus & 5 & 3 & 0 & 10 \\
\hline Rheumatoid arthritis & 11 & 4 & 0 & 2 \\
\hline Polyarteritis nodosa & 0 & 2 & 0 & 0 \\
\hline Wegener's granulomatosis & 1 & 0 & 0 & 0 \\
\hline Collagen disease-unspecified & 1 & 3 & 0 & 0 \\
\hline \multirow{2}{*}{\multicolumn{5}{|c|}{$\begin{array}{l}\text { Other immune-based and miscellaneous } \\
\text { disorders }\end{array}$}} \\
\hline & & & & \\
\hline Thyrotoxicosis & 1 & 1 & 0 & 1 \\
\hline Myxoedema & 0 & 2 & 0 & 0 \\
\hline Chronic active hepatitis & 1 & 0 & 0 & 0 \\
\hline Pernicious anaemia & 3 & 0 & 0 & 0 \\
\hline Diabetes mellitus & 2 & 2 & 0 & 1 \\
\hline Sarcoidosis & 1 & 1 & 0 & 1 \\
\hline Ulcerative colitis & 12 & 0 & 0 & 0 \\
\hline Myasthenia gravis & 1 & 0 & 0 & 0 \\
\hline AIH associated with pregnancy & 6 & 7 & 0 & 0 \\
\hline AIH associated with dialysis & 0 & 2 & 0 & 0 \\
\hline
\end{tabular}

association and type of AIH. Drug-associated haemolysis was always of the warm autoantibody type and was almost always secondary to treatment with $\alpha$-methyldopa; only one case was due to another drug - mefenamic acid (Ponstan).

The distribution of $\mathrm{ABO}$ and $\mathrm{Rh}$ genotypes did not differ significantly from that of a normal control population, with the exception of a slight excess of $\mathrm{Rh}$-negative individuals in the drug-associated group ( $p=0 \cdot 05$, Chi squared test). This significance was not evident when all cases of warm AIH were considered together.

Age at the time of presentation is shown in the figure: the early peak of cases with cold AIH is mainly due to patients with paroxysma cold haemoglobinuria. In all groups, with the exception of those with paroxysmal cold haemoglobinuria, there was a slight female predominance (the male:female ratio varied from $1: 1 \cdot 15$ to $1: 1 \cdot 33$ ).

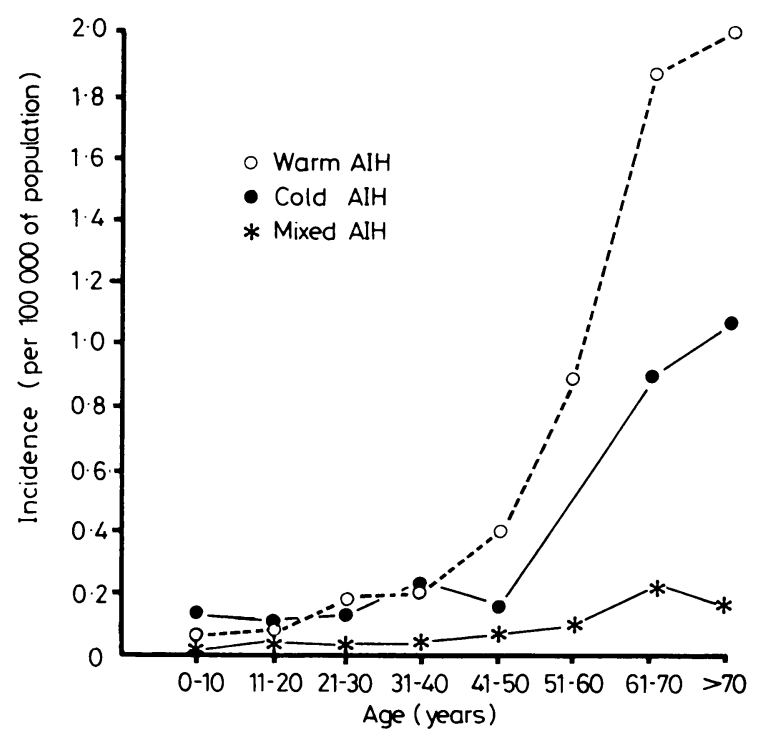

Age and incidence of AIH per 100000 of population at risk.

TABLE II-Results of direct antiglobulin tests in patients with AIH*

\begin{tabular}{lrrrrr}
\hline \multicolumn{1}{c}{$\begin{array}{c}\text { Direct antiglobulin } \\
\text { test }\end{array}$} & Warm AIH & $\begin{array}{c}\text { Drug } \\
\text { induced }\end{array}$ & Cold AIH & PCH & Mixed AIH \\
& & & & & \\
\hline Positive reactions with antisera to: & 218 & 146 & 2 & 0 & 10 \\
IgG & 86 & $9+$ & 3 & 0 & 40 \\
IgG and complement & 22 & 0 & 250 & 16 & 6 \\
Complement & 7 & 1 & 1 & 0 & 0 \\
IgG and IgM & 5 & 1 & 0 & 0 & 1 \\
IgG and IgA & 6 & 0 & 0 & 0 & 0 \\
IgG, IgM and IgA & 1 & 0 & 0 & 0 & 0 \\
IgM and complement & 2 & 0 & 0 & 0 & 0 \\
IgA and complement & 0 & 0 & 0 & 0 & 3 \\
IgG, IgA, and complement & 4 & 0 & 2 & 0 & 0 \\
Broad-spectrum reagents & 4 & 0 & 17 & 1 & 1 \\
Direct antiglobulin test result negative & & & & & \\
&
\end{tabular}

*Direct antiglobulin testing with monospecific anti-immunoglobulins was introduced in May 1977 and with monospecific anti-complement components in June 1978 results with the latter reagents have not been included in
tIncludes one patient with drug-associated mixed AIH.

The time of presentation was not related to the season of the year. Serological findings are shown in tables II, III, and IV. The autoantibodies (serum or eluate) showed evidence of blood group specificity in many instances (table IV); this was more obvious in patients with cold AIH. The specificity was rarely simple and, in nearly every case, pan-reacting antibodies could be detected by at least one method.

In cases associated with cold autoantibodies a small group of patients with paroxysmal cold haemoglobinuria could be separated on the basis of the serological reactions. Fifteen patients were found to have paroxysmal cold haemoglobinuria, confirmed by positive indirect Donath-Landsteiner tests (table III), and a further two were found during this review who, in retrospect, were almost certainly suffering from paroxysmal cold haemoglobinuria but in whom full serology was not carried out. Twelve patients were male and five female; 13 
were under 10 years and only one over 40 . In 16 instances the disease followed an acute course and in one (a patient aged 32) it was chronic; in the patients with acute disease the result of the direct antiglobulin test was weakly positive whereas in the patient with chronic paroxysmal cold haemoglobinuria the result of the direct antiglobulin test was negative (table II). Positive Wassermann complement fixation tests for syphilis were found in three patients, but in no case was a luetic infection confirmed.

TABLE III-Results of tests for in-vitro haemolysins in patients with AIH

\begin{tabular}{|c|c|c|c|c|c|}
\hline \multirow{2}{*}{$\begin{array}{l}\text { Haemolysin tests } \\
\text { No of patients tested }\end{array}$} & \multicolumn{2}{|c|}{$\begin{array}{c}\text { Warm AIH } \\
\text { Drug } \\
\text { induced }\end{array}$} & \multicolumn{2}{|c|}{ Cold $\underset{\text { PCH }}{\mathrm{AIH}}$} & Mixed AIH \\
\hline & 340 & 151 & 250 & 15 & 60 \\
\hline $\begin{array}{l}18 \mathrm{C} \text { and } 37 \mathrm{C} \text { at } \mathrm{pH} 6 \cdot 8 \text { and } \\
\text { papaimised cells } 37 \mathrm{C}\end{array}$ & 0 & 0 & 53 & 0 & 1 \\
\hline $\begin{array}{l}18 \mathrm{C} \text { at } \mathrm{pH} 6.8 \text { and papainised } \\
\text { cells } 37 \mathrm{C} \\
37 \mathrm{C} \text { at } \mathrm{pH} 6.8 \text { and papainised }\end{array}$ & 0 & 0 & 25 & 0 & 3 \\
\hline cells $37 \mathrm{C}$ & 1 & 0 & 5 & 0 & 2 \\
\hline $18 \mathrm{C}$ and $37 \mathrm{C}$ at $\mathrm{pH} 6.8$ & 1 & 0 & 14 & 0 & 0 \\
\hline $18 \mathrm{C}$ at $\mathrm{pH} 6.8$ & 1 & 0 & 25 & 0 & 3 \\
\hline Papainised cells $37^{\circ} \mathrm{C}$ & 17 & 0 & 28 & 0 & 16 \\
\hline Indirect $\mathrm{D}-\mathrm{I}$ & 0 & 0 & 0 & 12 & 0 \\
\hline $\begin{array}{l}\text { Indirect } \mathrm{D}-\mathrm{L} \text { and papainised } \\
\text { cells } 37 \mathrm{C}\end{array}$ & 0 & 0 & 0 & 2 & 0 \\
\hline $\begin{array}{l}\text { Indirect } \mathrm{D}-\mathrm{L} \text {, and } 18 \mathrm{C} \text { and } 37^{\circ} \mathrm{C} \\
\text { at } \mathrm{pH} 6.8\end{array}$ & 0 & 0 & 0 & 1 & 0 \\
\hline Haemolysins not detected & 320 & 151 & 100 & 0 & 35 \\
\hline
\end{tabular}

D-L = Donath-Landsteiner antibody

TABLE IV-Specificity of autoantibodies

\begin{tabular}{|c|c|c|c|}
\hline \multicolumn{2}{|l|}{ Warm autoantibodies } & \multicolumn{2}{|c|}{ Cold autoantibodies } \\
\hline Incomplete auto/pan antibody & 459 & Cold auto/panagglutinin & 120 \\
\hline Auto anti-e & 71 & $\begin{array}{l}\text { Cold auto panaglutinin } \\
\text { (not } \mathrm{I} / \mathrm{i} \text { specificity) }\end{array}$ & 21 \\
\hline $\begin{array}{l}\text { Auto anti-e and other auto } \mathrm{Rh} \\
\text { Auto } \mathrm{Rh} \text { (not anti-e) } \\
\text { Auto only (cells Ig(i sensitised) }\end{array}$ & $\begin{array}{r}7 \\
29 \\
8\end{array}$ & $\begin{array}{l}\text { Auto anti-I } \\
\text { Auto anti-i } \\
\text { Auto anti-N } \\
\text { Auto anti-A } A_{1} I \\
\text { Auto anti-A } 1 \\
\text { Auto anti-P }\end{array}$ & $\begin{array}{r}178 \\
15 \\
2 \\
2 \\
1 \\
1 *\end{array}$ \\
\hline
\end{tabular}

*Donath-Landsteiner antibody.

\section{Discussion}

Although autoimmune haemolytic anaemia is usually thought of as a well-defined clinical syndrome, the more closely cases are examined the more obvious it becomes that anaemia due to autoimmune haemolysis merely represents an extreme of a fundamental disturbance in immune homeostatis. As haemolysis may be present in the absence of anaemia we prefer the term autoimmune haemolysis, which refers to when a patient produces a protein that attaches to the autologous red cell and there is evidence that this causes a shortening of the red cell life span. This view is in broad agreement with those of other authors. ${ }^{1-5}$ Like all definitions, it has its limitations, diagnosis depending ultimately on the sensitivity of serological reactions and the estimation of the red cell life span in an often complicated situation. All the cases presented here (with the exception of some associated with $\alpha$-methyldopa treatment-to be discussed later) had good evidence of AIH.

More patients took part in this series than in other similar studies. ${ }^{24-6}$ During this 18 -year study our immunohaematology service has developed, and more sensitive and specific techniques have been introduced; a particular example has been the development of the direct antiglobulin test from the original tile method using "broad spectrum" reagents, with and without absorption with IgG, to the current tube techniques using monospecific antiglobulin and anticomplement reagents. These developments are still continuing and currently include the chromatographic separation of the warm and cold antibody components in cases of mixed AIH.

When the incidence of $\mathrm{AIH}$ is considered per 100000 of the population at risk it is seen that the disorder increases dramatically after 41-50 years, and the incidence continues to rise (fig). Using these parameters, the peaks of incidence in other series are seen to be just a reflection of the population at risk. ${ }^{6}$ Pirofsky ${ }^{5}$ found a one in 80000 minimum annual incidence of AIHA, which is of the same order as the present series; he also found an equal sex ratio that he attributed to the sex ratio of the underlying disorders-idiopathic AIHA and that associated with systemic lupus erythematosus were more common in women and AIHA associated with lymphoma and chronic lymphocytic leukaemia were more common in men. Our results show more women in all serological groups except those with paroxysmal cold haemoglobinuria. Cases of acute paroxysmal cold haemoglobinuria were also the exception to the increased incidence with age, patients usually presenting in childhood, often after a viral type infection; these findings were similar to those of other series, but male predominance was not reported..$^{4} 78$

The concept of secondary AIH is complicated. It may mean that the $\mathrm{AIH}$ is associated with the other disease with a greater frequency than can be explained by chance alone, or that the AIH resolves when the associated disease is corrected-for instance, ovarian dermoid cysts $\longrightarrow$ or that the two disorders are different parts of a complex immunologically mediated multisystem disorder. ${ }^{4}$ The distribution of the present cases in relation to other disorders is shown in table I. This table is modelled on previously published associations, ${ }^{2}$ and although the $\mathrm{AIH}$ is evidently secondary in most instances, the above considerations (and the accuracy of diagnosis of the referring doctor), should be borne in mind; for example, is there significance in the occasional association of $\mathrm{AIH}$ with the relatively common disorders of pernicious anaemia, rheumatoid arthritis, thyroid disease, diabetes mellitus, and certain infections or should this be regarded as a chance occurrence? The present finding of $40.9 \%$ of cases being apparently idiopathic may be compared with other published series, where they range from $18 \%$ (in warm AIHA) to $56 \%$ overall. ${ }^{5} 8$

A new classification of $\mathrm{AIH}$, based on the serological nature of the antibodies considered responsible for the haemolysis, is proposed (table I); it differs from the more traditional classifications of fairly clear cut warm and cold antibody associated groups (the latter including paroxysmal cold haemoglobinuria as a distinctive subgroup $)^{1258}$ in that a separate mixed category is introduced where both warm and cold reacting antibodies were shown, and the serological reactions were such that both types of antibody were considered capable of causing haemolysis. We think that this classification has advantages as it allows for the fact that $\mathrm{AIH}$ often does not fit neatly into one particular category and also that particular diseases are not necessarily always associated with either warm or cold groups (table I).

The result of the direct antiglobulin test was almost always positive (table II). No attempt has been made to correlate reaction patterns with idiopathic and secondary types of $\mathrm{AIH}$ because monospecific antiglobulin reagents, essential for this sort of study, were introduced into routine use only three and a half years ago. Other reports describe various reaction patterns for the direct antiglobulin test in AIHA and conclude that only in AIHA associated with systemic lupus erythematosus does there seem to be any sort of pattern; in these cases both IgG and complement are found on the red cells. ${ }^{2} 8$ The present findings differ and show that in patients with systemic lupus erythematosus (and other collagen diseases) the reaction pattern of the direct antiglobulin test varies. Occasionally patients present with strong evidence of $\mathrm{AIH}$ but with a negative direct antiglobulin test result. The reasons for this are diverse but basically too few antibody molecules are present on the red cell surface to be detected by conventional techniques. ${ }^{4} 9$ In our experience such cases have been less frequently encountered since the introduction of monospecific antiglobulin reagents.

The specificity of autoantibodies in AIH has been investigated 
in detail by other workers using rare cells and complicated absorption techniques. It is generally concluded that in cases of warm AIHA the antibodies usually show varying $\mathrm{Rh}$ specificity, in cases of cold the specificity is usually in the Ii system, and in paroxysmal cold haemoglobinuria in the $P$ system. With in-depth investigation, however, antibodies showing apparently simple specificities also usually react against basic cell membrane components. ${ }^{2-4} \times 1011$ Cells of rare genotypes are not available for general use even in a regional transfusion centre, and it is thought that the present investigations using serum and eluates, with and without absorption with selected cells, are all that are necessary to decide the most suitable genotype of donor blood for transfusion. This view does not undermine the fundamental importance of previous work, and, interestingly, the present series shows a preponderance of Rh-negative (rr) patients with $\alpha$-methyldopaassociated warm AIH. No explanation can be offered for this finding, and it should be remembered that the significance is only at the 0.05 level.

Cases of mixed AIH have not previously been defined as a separate group; they are of considerable interest and may be either idiopathic $(44.3 \%)$ or secondary (table I). Characteristically both IgG and complement coat the red cells in the direct antiglobulin test and the cold antibody component acts at $30^{\circ} \mathrm{C}$ or above in saline; the latter reaction distinguishes this group from patients with warm $\mathrm{AIH}$ and a raised level of cold agglutinins that do not react above room temperature. Patients with mixed AIH often have severe haemolysis, and the disease tends to run a chronic intermittent course. Few reports of similar cases of mixed AIH could be found; Petz and Garratty ${ }^{4}$ state that cases of warm AIHA with concomitant serological findings of cold agglutinin syndrome are rare and may be associated with lymphoproliferative states; the serological details of their four cases were similar to ours. A case of severe AIHA with similar findings has recently been described. ${ }^{12}$

The present results show that AIH associated with cold antibodies has a much more variable picture than the usually portrayed characteristic clinical syndrome with high titre cold agglutinins of wide thermal amplitude. ${ }^{128}$ Roughly $50^{\circ}$ only of our series (idiopathic and secondary) fitted into the typical cold agglutinin syndrome, the remainder showed low titre cold agglutinins associated with varying degrees of haemolysis. These findings are in agreement with those of some other workers who emphasised the importance of the thermal amplitude of the antibody in the development of haemolysis, activity at $30^{\circ} \mathrm{C}$ or above in albumin being the critical test for a diagnosis of cold agglutinin disease. ${ }^{413-16}$ Cold antibodies acting at $30 \mathrm{C}$ or above were shown (using the less sensitive saline technique) in nearly all of the present cases.

Drug-induced cases of AIH were almost entirely due to $\alpha$ methyldopa. Our series includes those patients in whom autoreacting and usually pan-reacting antibodies were present; cases with a positive direct antiglobulin test result but without circulating antibody were excluded as the consensus opinion is that these cases no not haemolyse. ${ }^{4}$ Some patients also had other conditions that may be associated with AIH but in these cases it was thought that the drug was the main aetiological agent. Our findings, on the whole, were similar to those of other reports, with warm-type AIH and IgG alone coating the red cells (except in a few cases where a complement component was also present). ${ }^{2}{ }^{4} \times 11^{18}$ The one patient with mixed type AIH was interesting as she had been taking $\alpha$-methyldopa for 12 years, initially $250 \mathrm{mg}$ twice daily, but this had been doubled 11 months before presentation; the cold antibody component was of low titre and showed anti-I specificity. Whether the cold antibody was coincident was not known, but the severe haemolysis rapidly stopped after cessation of $\alpha$-methyldopa and a short course of steroids. Despite a positive direct antiglobulin test result and the presence of circulating antibody some patients taking $\alpha$-methyldopa do not have evidence of a haemolytic anaemia. ${ }^{+818}$ They may have mild compensated haemolysis, but in a few cases the red cell life span has been measured and in some instances found to be normal ${ }^{119}$; possibly a few of our cases fit into this category. Measurement of red cell life span has rarely been carried out in patients with $\mathrm{AIH}$, but these findings suggest it should become an important definitive investigation in the future. AIH due to mefenamic acid (Ponstan) is rare, and our one case, which was well documented, occurred in a patient with chronic granulocytic leukaemia; the haemolysis rapidly ceased when the drug was stopped.

AIHA associated with pregnancy is rare. The present series, which includes only those patients who presented during pregnancy or in the immediate postnatal period, is the largest number of cases examined by one group; patients with preexisting systemic lupus erythematosus or other disorders that might have caused the AIH and patients with known AIH who become pregnant are excluded. In most instances the disease was mild and in six was initially discovered at routine antenatal testing; only three patients had a severe haemolytic anaemia. Details of the babies' clinical condition were not complete, but nine (including one set of twins) are known to have been well and only two were ill, one of the latter suffering from haemolytic disease of the newborn due to anti- $\mathrm{Rh} \mathrm{D}$. These findings differ from those of previous reports, ${ }^{40}$ which concluded that AIHA during pregnancy is often severe and life threatening to the mother in $40-50 \%$ of cases and causes stillbirth or postpartum haemolytic anaemia in $35-40 \%$ of infants. These reports, however, did not distinguish pregnancy occurring in patients with known AIHA from AIHA arising during pregnancy.

Two patients undergoing renal dialysis were found to have cold AIH due to auto anti $\mathrm{N}$; the haemolysis was mild in the patient with an $M N$ genotype and moderate in the other with NN. These cases were similar to those of Fassbinder et al ${ }^{21}$ where auto anti-N-like antibodies developed in $68(20.9 \%)$ of 325 patients on haemodialysis who used formaldehyde to sterilise their dialysers; transfusion experiments in vivo confirming the haemolytic activity of the antibodies which was more pronounced with NN cells.

We thank Dr W Wagstaff and Professor G Hudson for helpful advice, Mr D Foulds of the medical statistics department of the Trent Regional Health Authority for providing the population details, Miss $\mathrm{J}$ Sunderland for secretarial help, and our haematology colleagues for providing samples and details of their patients.

\section{References}

Brown DL. Acquired haemolytic anaemias: immune and non-immune. In: Hoffbrand AV, Lewis SM, eds. Tutorials in postgraduate medicine, 2: Haematology. London: William Heineman, 1972:217-56.

Dacie JV, Worlledge SM. Auto-immune hemolytic anemias. Prog Hematol $1969 ; 6: 82-120$

Flaherty T, Geary CG. Autoimmune haemolytic anaemia. Br f Hosp Med $1979 ; 22: 334-45$.

1 Petz LD, Garratty G. Acquired immune hemolytic anemias. New York: Churchill Livingstone, 1980.

Pirofsky B. Clinical aspects of autoimmune hemolytic anemia. Semin Haematol 1976;13:251-65.

${ }^{6}$ Salmon C, Homberg J-C, Habibi B. Immunologie des anémies hémolytiques auto-immunes. Rev Fr Transfus Immunohematol 1975;18:497-514.

Bird GWG, Wingham J, Martin AJ, et al. Idiopathic non-syphilitic paroxysmal cold haemoglobinuria in children. F Clin Pathol 1976;29: 215-8.

Worlledge S. Immune haemolytic anaemias. In: Hardisty RM, Weatherall DJ, eds. Blood and its disorders. Oxford: Blackwell, 1972:714-62.

${ }^{9}$ Gilliland BC. Coombs-negative immune hemolytic anemia. Semin Haematol 1976;13:267-75.

10 Isitt PD, Pavone BG. Critical re-examination of the specificity of autoanti- $\mathrm{Rh}$ antibodies in patients with a positive direct antiglobulin test. Br F Haematol 1978;38:63-74.

11 Vos GH, Petz LD, Fudenberg HH. Specificity and immunoglobulin characteristics of autoantibodies in acquired hemolytic anemia. $f$ Immunol $1971 ; 106: 1172-6$.

12 Patten E, Reuter FP. Evan's syndrome: possible benefit from plasma exchange. Transfusion 1980;20:589-93.

${ }^{13}$ Garratty G, Petz LD, Hoops JK. The correlation of cold agglutinin titrations in saline and albumin with haemolytic anaemia. BrF Haematol $1977 ; 35$ :587-95. 
14 Pruzanski W, Shumak KH. Biologic activity of cold-reacting autoantibodies (first of two parts). N Engl f Med 1977;297:538-45.

15 Pruzanski W, Shumak KH. Biologic activity of cold-reacting autoantibodies (second of two parts). N Engl f Med 1977;297:583-9.

${ }^{16}$ Schreiber AD, Herskovitz BS, Goldwein M. Low-titer cold-hemagglutinin disease: mechanism of hemolysis and response to corticosteroids. $N$ Engl f Med $1977 ; 296: 1490-4$.

17 Petz LD. Drug-induced immune haemolytic anaemia. Clin Haematol $1980 ; 9: 455-82$.

18 Worlledge SM. Immune drug-induced haemolytic anaemias. Semin Haematol $1969 ; 6: 181-200$.

19 Silvergleid AJ, Wells RF, Hafleigh EB, Korn G, Kellner JJ, Grumet FC.
Compatibility test using ${ }^{51}$ chromium-labeled red blood cells in crossmatch positive patients. Transfusion 1978;18:8-14.

${ }^{20}$ Chaplin H, Cohen R, Bloomberg G, Kaplan HJ, Moore JA, Dorner I. Pregnancy and autoimmune haemolytic anaemia: a prospective study during six months' gestation and three months' post-partum. $\mathrm{Br} \mathcal{F}$ Haematol 1973;24:219-29.

${ }^{21}$ Fassbinder W, Seidl S, Koch KM. The role of formaldehyde in the formation of haemodialysis-associated anti-N-like antibodies. Vox Sang $1978 ; 35: 41-8$.

(Accepted 14 May 1981)

\title{
For Debate
}

\section{Rheumatoid arthritis and food: a case study}

\author{
A L PARKE, G R V HUGHES
}

\begin{abstract}
Clinical and laboratory studies in a patient whose rheumatoid arthritis appeared to be exacerbated by dairy produce showed that challenge with milk and cheese resulted in a pronounced increase in synovitis and changes in immune complexes, IgE antibodies, and heat-damaged red cell clearance rates. Exclusion of dairy produce from the diet produced a considerable improvement in her previously aggressive disease.
\end{abstract}

Despite an increasing interest in the potentially pathogenic effects of food allergy and despite the conviction of innumerable patients with rheumatoid arthritis that certain foods exacerbate their disease, little scientific attention has been paid to the relation between ingested food antigen and rheumatoid disease activity. Recent studies have shown that the absorption of food antigen may be associated with the development of circulating immune complexes in some patients with IgA deficiency or with food antigen sensitivity as well as in certain normal individuals, ${ }^{1-3}$ and that certain non-human proteins such as casein may become deposited in the skin of such people. ${ }^{4}$

As part of a larger study of the effects of certain food proteins on immunological measures in rheumatic disease, we have recently observed a patient in whom the ingestion of cheese and other dairy products had an immediate and profound effect on her clinical and immunological state. Restriction of these foods produced a prolonged improvement in the patient's previously unresponsive arthritis.

\section{Case report}

In November 1979 a 38-year-old mother of three children presented with an 11-year history of progressive, erosive seronegative rheumatoid

\footnotetext{
Rheumatology Unit, Hammersmith Hospital, Royal Postgraduate Medical School, London W12 OHS

A L PARKE, MB, FRCP(c), honorary senior registrar

G R V HUGHES, MD, FRCP, consultant physician and senior lecturer in medicine
}

arthritis. Conventional treatment with salicylates and non-steroidal anti-inflammatory agents had failed. Both gold and penicillamine treatment had had to be discontinued owing to mucocutaneous side effects, and prednisolone $10 \mathrm{mg}$ daily (which she was still taking) had failed to relieve the intense synovitis and stiffness. Plasma exchange was tried, and although she obtained some relief this benefit was short lived. Azathioprine was also tried but was stopped because of intestinal upset.

The patient gave a history of multiple drug allergies, including sensitivity to penicillin, as well as the toxic manifestations of gold and penicillamine treatment. She had developed severe gastrointestinal discomfort associated with aspirin, indomethacin, and azathioprine, and rashes related to Elastoplast and detergents. At no time had she experienced respiratory symptoms on exposure to these chemicals, and she had never noticed an exacerbation of her arthritis after such exposure. Her mother (who also has rheumatoid arthritis) was similarly reactive to Elastoplast, penicillin, detergents, and aspirin, and also nickel. Her sister and niece both have asthma.

On examination, she was a pale, unwell young woman with widespread intense synovitis affecting both large and small joints symmetrically. Stiffness as well as fatigue lasted for several hours each day. There were no nodules. There was dryness of the eyes and mouth and a dry Schirmer's test. Grip strengths were weak $(110 \mathrm{~mm}$ with the left hand and $120 \mathrm{~mm}$ with the right hand) and the Ritchie index of articular activity ${ }^{5}$ was high at 42 . Investigations showed a normochromic, normocytic anaemia of $10.5 \mathrm{~g} / \mathrm{dl}$, an erythrocyte sedimentation rate of $110 \mathrm{~mm}$ in the first hour, and normal immunoglobulins. IgM rheumatoid factor tests (Latex and sheep cell agglutination) were negative on numerous occasions. Circulating immune complexes as measured by the Clq binding method ${ }^{6}$ and the rheumatoid factor binding method were present in a titre of greater than $250 \mu \mathrm{g}$ equivalents of heat-aggregated human IgG. No cryoprecipitate was detected. C3 concentrations were normal at $96 \%$ of normal human serum, and total haemolytic complement activity was $60-90 \%$ of normal human serum. Estimates of reticuloendothelial function using clearance of heat-damaged red cells ${ }^{7}$ showed prolonged clearance on more than one occasion. Radiographs showed many erosions in the carpus and metacarpal phalangeal joints as well as proximal interphalangeal joints and metatarsal phalangeal joints.

\section{TREATMENT AND PROGRESS}

Since her early 20 s the patient had had a passion for cheese, consuming up to $1 \mathrm{lb}(0.4 \mathrm{~kg})$ a day. Although there was no clear history of allergy or diarrhoea after eating cheese she agreed to try the effect of restricting dairy produce, with the elimination of milk, 